\title{
VALUE INVESTING ANALYSIS OF BANKING SECTOR ON BIST-100
}

\author{
DOI: 10.17261/Pressacademia.2021.1394 \\ JEFA- V.8-ISS.2-2021(2)-90-101
}

\author{
Ozlem Ozarslan Saydar ${ }^{1}$, Canpolat Bedir ${ }^{2}$ \\ ${ }^{1}$ Nisantasi University, Department of Capital Markets and Portfolio Management, Sariyer, Istanbul, Turkey. \\ ozlem.saydar@nisantasi.edu.tr, ORCID: 0000-0001-8427-6298 \\ ${ }^{2}$ Altinbas University, Institute of Social Sciences, Department of Financial Economics, Esentepe, Istanbul, Turkey. \\ Canpolat14@gmail.com , ORCID: 0000-0002-3847-5779
}

Date Received: March 3, 2021

Date Accepted: May 29, 2021 open Daccess $(c)$ BY

To cite this document

Saydar, O.O., Bedir, C., (2021). Value investing analysis of banking sector on BIST-100. Journal of Economics, Finance and Accounting (JEFA), $8(2), 90-101$.

Permanent link to this document: http://doi.org/10.17261/Pressacademia.2021.1394

Copyright: Published by PressAcademia and limited licensed re-use rights only.

\begin{abstract}
Purpose- The main goal of this study is to apply the value investing criteria to a selected portfolio and to test the validity of basic value investment hypothesis. The return performance of the selected portfolio was examined over the other bank stocks in addition to assessing the risk and return criteria (Sharpe Ratio). The efficient ratio (Price/Book Value vs Price/Earnings ratios) in the formation of the selected portfolio is further explored. The paper aims to prove the existence of margin over $\mathrm{P} / \mathrm{B}$ Value and $\mathrm{P} / \mathrm{E}$ ratios to the banking sector in Turkey. Methodology- A universe of 6 banks ( 3 state and 3 private) trading in BIST-100 were selected within the framework of this analysis. BIST100 , MATRIKS DATA ${ }^{\mathrm{TM}}$ database was used to compile data for six selected banking stocks, for the 95 months period between February 2011 to December 2018. The performance of the selected portfolio was benchmarked over the control portfolio for the relevant financial year. Findings- In line with the results of the analysis and as observed in developed markets, the value investing strategies implemented for the selected banking shares listed in BIST-100, offer significantly high returns to the investors. Consequently, an investing strategy grounded on $\mathrm{P} / \mathrm{E}$ ratio is more profitable than a value investing strategy relying on $\mathrm{P} / \mathrm{B}$ ratio. The study thus demonstrates that the shares selected within the framework of the value investing concept garner superior returns compared to benchmark portfolio.

Conclusion- As observed in developed markets, the value investing strategies implemented for the selected banking shares listed in BIST-100 results in significantly high returns for the investors. An investing strategy grounded on $\mathrm{P} / \mathrm{E}$ ratio is therefore more profitable than a value investing strategy relying on $\mathrm{P} / \mathrm{B}$ ratio.
\end{abstract}

Keywords: Value investing, Price/Book value, Price/Earnings ratio, selected portfolio, benchmark portfolio. JEL Codes: C87, G10, G11

\section{INTRODUCTION}

The basic concept of Value Investing is "Buying a business for far less than it is worth" (Browne, 2007), and it has gained prominence as an investment philosophy since the early 1930's. It is based on two principles: 1) Intrinsic value and 2) Margin of safety. Value investing consists of finding and buying securities that are priced below their intrinsic value.

Value investing strategies date back to the studies of Benjamin Graham and David Dodd (1934), premised on the idea of investing into undervalued but profitable shares. They proposed a clear definition of investment that is distinguished from what they deemed as speculation; "An investment operation is one which, upon thorough analysis, promises safety of principal and an adequate return. Operations not meeting these requirements are speculative". Klarman (1991) describes value investing as the investment strategy with a priority to deploy capital into undervalued stocks and to retain them until they reach intrinsic value, and the key point of the strategy is to invest into bargain and overlooked shares.

Applying the stock analysis method to the concept of value investing assists in determining a stock's real value at the time of purchase of the stock whose current share price is below its genuine value or worth. The theory is applicable to various markets and periods, though the market realization remains highly controversial. Contrary to the basic notion of Efficient Market Theory which posits that the price of a share reflects all the available information about the intrinsic value of the 
share; it can be proven that a premium margin exists between the trading value and the intrinsic value. The focus of behavioural finance studies weighs heavily on the application of theories to reveal this disparity.

The aim of this study is to prove the existence of this margin over Price/Book Value and Price/Earnings ratios in the banking sector in Turkey. To achieve this, the value investing criteria were applied to a selected portfolio to test the validity of the basic value investment hypothesis. The return performance of the selected portfolio was examined over the other bank stocks whilst evaluating the risk and return criteria (Sharpe Ratio). Furthermore, the efficient ratio $(P / E v S P / B)$ in the formation of the selected portfolio is explored.

The analysis is based on $\mathrm{P} / \mathrm{E}$ and $\mathrm{P} / \mathrm{B}$ ratios considered as the basic multiples for the value investment strategy. Two different software were used for data processing in the study. MS EXCEL ${ }^{\mathrm{TM}}$ was used for portfolio selection, performance comparison and metric measurements. STATA ${ }^{\mathrm{TM}} 13.0$ statistical data processing program was used for data modelling. One state and one private bank shares with the lowest P/E multiple were selected at the end of each financial year. The performance of the selected portfolio was benchmarked over the control portfolio for the relevant financial year.

The following section of this paper provides a literature review on value investing method and its application on different stock markets. Besides the data provided, the scope of the analysis and methodology are explained in Section 3, and Section 4 comprises of the findings and presents a brief conclusion of the study.

\section{LITERATURE REVIEW}

The considered positions of Bellone and Carvalho (2021) concerning "valuations of value stocks" spreads in relation to "their most expensive peers" are: (1) of complete regional and macro-sectors expansion, circa 2020. (2) Levels of value spreads compared with high favourability to the 2000, "Tech Bubble". (3) Compression of value spreads is projected forward with high probability, on the basis of 2001 value spreads peak. The conclusion Bellone and Carvallo draw when they categorically state the followings supports the findings established in "Value Investing Analysis of Banking Sector on BIST-100": "Value stocks are simply as cheap, relatively speaking, as they have ever been while the opposite is the case for expensive stocks. While irrational exuberance can be sustained or even extended for some time longer, compression of value spreads over the next few years is the more likely scenario. That should be positive for value stocks, small capitalization stocks and for diversified multifactor investing approaches." (Bellone and Carvalho, 2021).

Their stated positions above support the overriding prognosis of this paper in line with the results of the analysis observed in developed markets, that the value investing strategies implemented for the selected banking shares listed in BIST-100, have offered significantly high returns to the investors; Bellone and Carvalho expanded their perspective to caution against value investing capitulation as a probable "costly decision".

Blitz and Hanauer (2020) conclusion is in alignment with this study when they confirmed that: "Based on these results \{they\} conclude that \{their\} various enhancements to the standard value factor are effective at resurrecting the value premium. In other words, they resurrected the value premium". Their underlying rationale which reviewed "the valuation spread" of the nineties, based on a "mean-reversion of the year 2000 "valuation spread" resulted in what is described as "massive outperformance of value stocks over the growth stocks". Taken together with their further observations such as the establishment of "a significant positive relation between valuation spreads and the future value premium" by the other researchers of their citation and the interconnectedness with the "net spread widening" which happened over their sample periods - The divergence of "valuation multiples between value and growth stocks" - their inconsistence in the buying and selling of shares using arbitrage when significant amount of money has been "invested in value strategies" are disposed towards the raising of "the value premium." (Blitz and Hanauer, 2020).

Sharpe et al. (1993) conducted a research to compare the performance of value and growth shares in six developed markets including France, Germany, Switzerland, England, Japan, and USA. They select the P/B ratio to determine the portfolio of value and growth shares. The findings of their research demonstrate that the prominence of value-growth factors in the markets and the value shares offer superior performance than growth shares in all markets during the analysis period.

Lakonishok et al. (1994) examined the underlying reasons for the stronger returns offered by the value investing strategies to exemplify the controversial approach versus the conventional investment strategies adhered to by the bulk of the investor community.

Covering 21 stock exchanges including USA, Europe, Australia, and the Far East over the period between 1975-1995 and based on Price/Earnings, Price/Book, Cash Flow/Price and Dividend/Price ratios and the value stocks, the study conducted by Fama and French (1998) reveals that higher returns are obtained in comparison to growth stocks in all stock exchanges under 
review. Furthermore, Price/Book ratio performance of value stocks surpasses similar performance of growth stocks in 12 out of 13 leading stock exchanges.

Håkansson and Kvarnmark (2016) investigated whether the 'magic formula' can yield superior investment returns depending on the risk taken. The concept of magic formula introduced by Joel Greenblatt, describes a systematic approach to successful stock investing. To examine the potential relation between the magic formula and superior investment returns, they tested the formula on the Nordic Stock Market between 2007 and 2016 and compared the returns of the portfolio to the benchmark OMX Nordic 40. They apply the Capital Asset Pricing Model together with the Fama-French Three-Factor Model to determine how the portfolio yields high returns in relation to each unit of risk. They reveal that although the magic formula portfolio was significantly less diversified than the OMX Nordic 40, it had performed better during the setback of 2008 and 2009.

The study conducted by Piotroski (2000) demonstrates that the firms with higher Return on Asset (ROA) and operational cash flows, better profit margins, higher asset turnover ratios; produce higher returns. Piotroski proposes a compound F-Score using eight basic indicators related to firm performance. The study demonstrates that the high performing shares are recognized better in a large group of shares having the lowest $P / B$ ratios.

In another analysis, Mohanram (2005) confirmed the companies with higher P/B called 'growth shares' perform better than the other stocks.

Gönenç and Karan (2003) compared the returns between value shares to growth shares as well as small-scale portfolios to large-scale portfolios in Borsa Istanbul (BIST). Covering 1993-1998, value and growth stocks were selected in relation to P/B ratio, taken as sampling in the study. The results present superior performance of growth portfolios to value portfolios, which are highly unpredictable in developing markets.

Karcıoğlu (2017), analysis of 'value based portfolios' in three different periods covering 1996-2007, 2000-2011 and 2004-2015 supports the study's assessment that the efficiency of value investing strategies in different types of market conditions yield stronger returns in BIST relative to the returns observed in developed markets. Tripling of profitability in case of a longer duration is further reiterated. Based on an extensive data analysis, Srivastava, and Lev (2019) "show that value investing has generally been unprofitable for almost 30 years, barring a short resurrection following the dotcom bust." They "identify two major reasons for the failure of value investing: (1) accounting deficiencies causing systematic misidentification of value and particularly of glamour (growth) stocks, and (2) fundamental economic developments which slowed down significantly the reshuffling of value and glamour stocks (mean reversion) which drove the erstwhile gains from the value strategy." This research provides identification of the type of companies (stocks) that may still generate gains from value investing.

Lee (2014) reviews the theoretical foundations of value investing model, including (a) a noise trader framework for understanding that phenomenon and (b) an accounting-based valuation framework for reconciling the vast empirical evidence. He also evaluates the investment approaches of some well-known fundamental investors. He claims accounting information can help evaluate not only the first moment of a firm's future cash flows (i.e., the numerator of the future payoffs) but also its second moment (i.e., the riskiness of these payoffs). According to the author, as valuation theory shows, both elements are useful in evaluating the present value of a firm's future growth opportunities. Lee $(2014$, p.32) finally highlights buying "quality firms at reasonable prices and using historical-based accounting numbers to help investors achieve that task": It provides them an edge in their investing and help make markets more efficient as well.

Sareewiwatthana (2014) examines the concept of value investing, whereby PE, PEG, and PERG ratios are used for stock screening. The author concludes portfolios of low PERG using Standard Deviation as risk proxy provide better performances and PE displays the best screening, offering the highest returns during the period tested.

\section{DATA AND METHODOLOGY}

\subsection{Purpose of Study}

The main goal of this study is to apply the value investing criteria to a selected portfolio and to test the validity of basic value investment hypothesis. The study examines the return performance of the selected portfolio over the other bank stocks in cognizance of the risk and return criteria (Sharpe Ratio). In addition, the efficient ratio (P/E vs P/B) in the formation of the selected portfolio was explored.

\subsection{Scope of the Analysis and Methodology}

Graham (1949) proposes selection criteria based on firm's historical performance and financial standing to facilitate investment strategies of conservative investors. These criteria are as follows: 
1. Business Scale: The aim of this criterion is to eliminate small businesses more vulnerable to market fluctuations.

2. Financial Adequacy: Current ratio should be $2 x$ at minimum and long-term liabilities should not exceed net current assets. Additionally, the total indebtedness should not be above twice the book value for service companies.

3. Sustainable Profitability: The selected company should have recorded profits over the past 10 years.

4. Dividend History: The selected company should have constantly distributed dividends for the last twenty years.

5. Earnings Growth: Based on the last 10 years data, the average earnings per share (EPS) of the last 3 years should be compared to the average EPS of the first 3 years and EPS should have increased by $1 / 3$.

6. Price/Earnings ( $P / E)$ Ratio: Current market price should not exceed $15 x$ of the average profit of the last 3 years.

7. Price/Assets Ratio: Current market price should not exceed $1.5 x$ of the latest book value. $P / E x P / B$ ratio should remain below $22,5 x$ as a rule.

In consideration of the fact that each sector has different business dynamics and financial ratios and for the sake of the analysis only shares from the banking sector have been selected. Banking sector is also a strong indicator of the macro backdrop and has a significant weight in BIST-100 Index. Homogeneous portfolio selection also secures to minimize the magnitude of standard deviations.

The analysis was based on $\mathrm{P} / \mathrm{E}$ and $\mathrm{P} / \mathrm{B}$ ratios considered as the basic multiples for the value investment strategy. The stocks were classified by their monthly P/E ratios ${ }^{1}$. BIST-100, MATRIKS DATA ${ }^{\mathrm{TM}}$ database was used to compile data for six selected banking stocks, for the 95 months period between February 2011 to December 2018. One state and one private bank share with the lowest P/E multiple has been selected by the end of each financial year. The performance of the selected portfolio was benchmarked over the control portfolio for the relevant financial year. The performance is calculated as follows:

Return Formula,

$$
R=\frac{V_{f}-V_{i}}{V_{i}}
$$

$V_{f}=$ Ending period value (Including dividends)

$V_{i}=$ Beginning Period value

\section{$\mathrm{P} / \mathrm{E}$ and $\mathrm{P} / \mathrm{B}$ Calculations}

As provided below, $\mathrm{P} / \mathrm{E}$ ratio is calculated by comparing the market price of the stock to earnings per share. $\mathrm{P} / \mathrm{B}$ ratio is calculated by comparing the market price of the stock to the book value.

$$
\frac{P}{E} \text { Ratio }=\frac{\text { Price per Share }}{\text { Earnings per Share }} \quad \frac{P}{B} \text { Ratio }=\frac{\text { Price per Share }}{\text { Book Value per Share }}
$$

\subsection{Data Analysis and Portfolio Selection}

Two different software were used for data processing in the study. MS EXCEL ${ }^{\mathrm{TM}}$ was used for portfolio selection, performance comparison and metric measurements. STATA ${ }^{\mathrm{TM}} 13.0$ statistical data processing program was used for data modelling.

The $\mathrm{P} / \mathrm{E}$ ratios for the analysis period are presented below:

Table 1: Yearly P/E Ratios

\begin{tabular}{lcccccccc}
\hline Average P/E Ratio & $\mathbf{2 0 1 1}$ & $\mathbf{2 0 1 2}$ & $\mathbf{2 0 1 3}$ & $\mathbf{2 0 1 4}$ & $\mathbf{2 0 1 5}$ & $\mathbf{2 0 1 6}$ & $\mathbf{2 0 1 7}$ & $\mathbf{2 0 1 8}$ \\
\hline VAKBN & 6.90 & 7.30 & 8.25 & 7.20 & 6.16 & 5.35 & 4.80 & 3.40 \\
\hline SKBNK & 6.76 & 6.91 & 8.11 & 11.26 & 8.86 & 18.83 & 12.14 & 12.39 \\
\hline ISCTR & 7.52 & 7.93 & 7.60 & 7.91 & 7.38 & 6.39 & 6.00 & 4.55 \\
\hline HALKB & 7.22 & 8.12 & 7.70 & 6.98 & 6.86 & 4.70 & 4.99 & 2.85 \\
\hline GARAN & 9.56 & 10.24 & 10.89 & 12.02 & 10.56 & 8.28 & 7.41 & 5.42 \\
\hline AKBNK & 10.70 & 12.70 & 10.03 & 10.81 & 9.81 & 8.86 & 7.53 & 5.15 \\
\hline
\end{tabular}

\footnotetext{
${ }^{1} \mathrm{P} / \mathrm{E}$ Ratio announced on the last day of the relevant month.
} 
Table 1 lists the private and state bank shares with the lowest P/E ratios on the yearly basis. Each year the lowest values are highlighted by red colour for both state and private banks. These shares form the 'value portfolio' and the return performance of the value portfolio will be measured against the other banking shares classified as the 'control portfolio'.

For example, the shares with the lowest $\mathrm{P} / \mathrm{E}$ in 2011 have been selected as the value portfolio and the portfolio's performance is measured in 2012 .

In Table 2, selected state and private banks are presented on the lowest P/E base.

Table 2: State and Private Banks on the Lowest P/E Base

\begin{tabular}{lcccccccc}
\hline $\begin{array}{l}\text { Value } \\
\text { Stocks }\end{array}$ & $\mathbf{2 0 1 1}$ & $\mathbf{2 0 1 2}$ & $\mathbf{2 0 1 3}$ & $\mathbf{2 0 1 4}$ & $\mathbf{2 0 1 5}$ & $\mathbf{2 0 1 6}$ & $\mathbf{2 0 1 7}$ & $\mathbf{2 0 1 8}$ \\
\hline Public & SKBNK & SKBNK & HALKB & HALKB & VAKBN & HALKB & VAKBN & HALKB \\
\hline Private & ISCTR & ISCTR & ISCTR & ISCTR & ISCTR & ISCTR & ISCTR & ISCTR \\
\hline
\end{tabular}

\subsection{Performance Analysis and Benchmarking of the Value Portfolio}

Average rate of returns of Value Stocks portfolio are compared with three different groups of assets to benchmark their performance. Control stocks are the remainder of the banking stocks after the Value Stocks are selected. Risk Free Treasury Rate refers for the annual rate of return of the Treasury bills and BIST 100 index average annually returns are referred as BIST 100 in the Table below.

Average rate of returns for the seven-year period between 2012-2018 are presented in Table 3.

Table 3: Yearly Average Rate of Returns on Portfolio Basis

\begin{tabular}{llllllll}
\hline ARR of Portfolio & $\mathbf{2 0 1 2}$ & $\mathbf{2 0 1 3}$ & $\mathbf{2 0 1 4}$ & $\mathbf{2 0 1 5}$ & $\mathbf{2 0 1 6}$ & $\mathbf{2 0 1 7}$ & $\mathbf{2 0 1 8}$ \\
\hline Value Stocks & $\mathbf{7 8 . 2 \%}$ & $-8.4 \%$ & $48.7 \%$ & $-33.5 \%$ & $16.4 \%$ & $9.6 \%$ & $-44.5 \%$ \\
\hline Control Stocks & $48.6 \%$ & $-24.4 \%$ & $38.3 \%$ & $-23.4 \%$ & $-3.5 \%$ & $36.4 \%$ & $-34.2 \%$ \\
\hline Risk Free Treasury Rate & $8.7 \%$ & $8.0 \%$ & $9.3 \%$ & $9.3 \%$ & $10.2 \%$ & $11.1 \%$ & $15.9 \%$ \\
\hline Bist 100 & $45.2 \%$ & $-11.3 \%$ & $25.8 \%$ & $-16.7 \%$ & $9.9 \%$ & $41.2 \%$ & $-21.5 \%$ \\
\hline
\end{tabular}

Cumulative Returns of a 100-unit investment of Value Stocks vs Control, 10-Years Bond, BIST-100 for the end of 7 years are as follows:

Figure 1: Annual Returns of Value Stocks, Control Stocks, 10-Years Bond, BIST-100

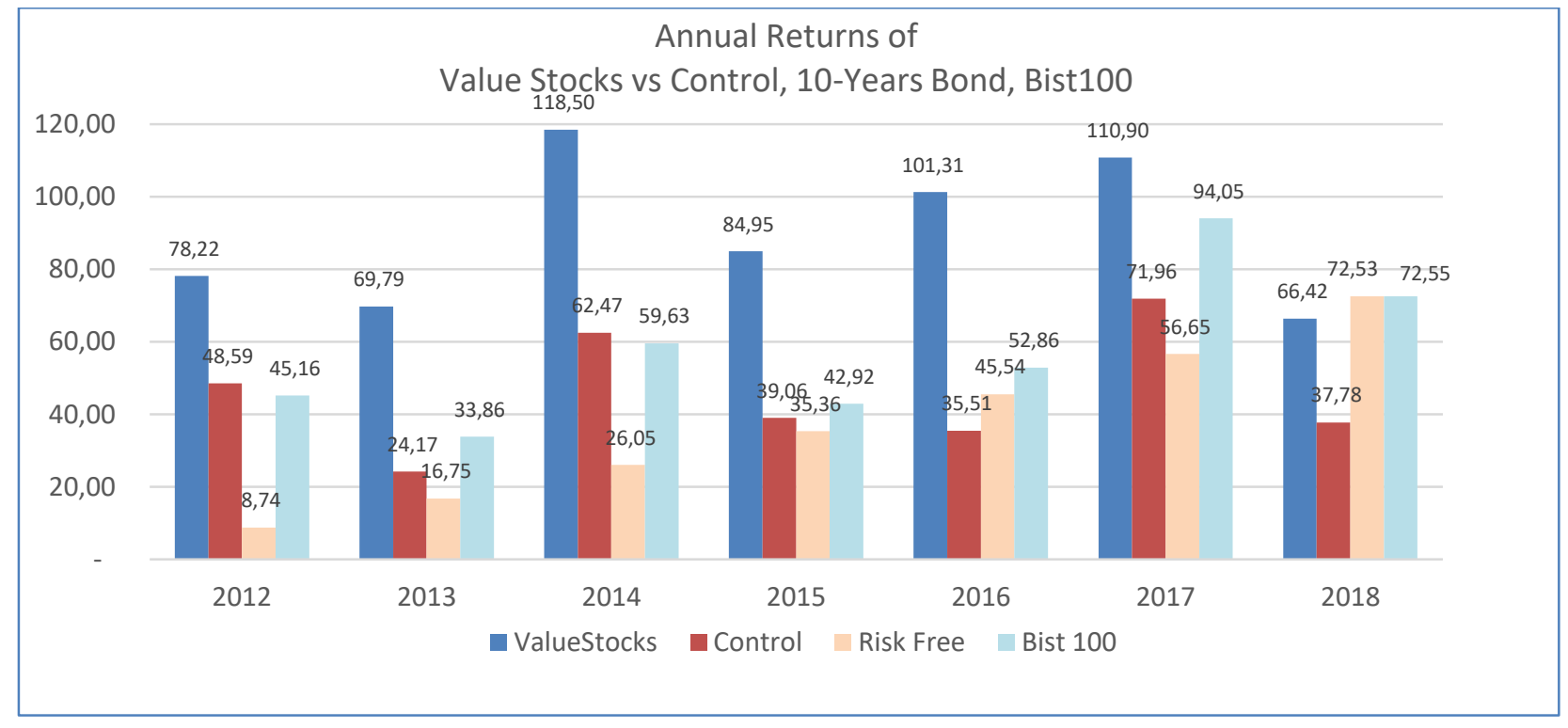


Table 4: Cumulative Return Index of Value Portfolio and Other Portfolios

\begin{tabular}{llllllll}
\hline $\begin{array}{l}\text { Cumulative Returns } \\
\text { Index }\end{array}$ & $\mathbf{2 0 1 2}$ & $\mathbf{2 0 1 3}$ & $\mathbf{2 0 1 4}$ & $\mathbf{2 0 1 5}$ & $\mathbf{2 0 1 6}$ & $\mathbf{2 0 1 7}$ & $\mathbf{2 0 1 8}$ \\
\hline Value Stocks & 78.22 & 69.79 & 118.50 & 84.95 & 101.31 & 110.90 & 66.42 \\
\hline Control & 48.59 & 24.17 & 62.47 & 39.06 & 35.51 & 71.96 & 37.78 \\
\hline Risk Free & 8,74 & 16.75 & 26,05 & 35.36 & 45.54 & 56.65 & 72.53 \\
\hline Bist 100 & 45.16 & 33.86 & 59.63 & 42.92 & 52.86 & 94.05 & 72.55 \\
\hline Value vs Control \% & $61.0 \%$ & $188.7 \%$ & $89.7 \%$ & $117.5 \%$ & $185.3 \%$ & $54.1 \%$ & $75.8 \%$ \\
\hline
\end{tabular}

According to the analysis;

1. Value portfolio has recorded higher returns relative to control portfolio in 2012, 2013³, 2014 and 2016.

2. The cumulative return of the value portfolio has outperformed the control portfolio by $110 \%$. (Value portfolio/Control portfolio - 1)

3. The banking sector shares have underperformed BIST-100 shares in 2018.

Value portfolio has lost its value by more than $2 x$ than the market average in 2018. This performance leads to the idea of a Value Trap ${ }^{4}$ that could occur in bear market conditions; however, the reliability of this argument needs to be tested in longer periods.

Fama and French (1992) have explained the major underlying driver of superior performance of value strategies with their higher risks. The investors receptive to invest into shares with lower P/E are awarded for the associated risks. (Pätäri \& Leivo :2009).

Sharpe ratios of the portfolios have been presented in Table 5 in order to calculate risk and return sensitivity.

Table 5: Value Stocks - Sharpe Ratios on Portfolio Basis - Yearly

\begin{tabular}{llllllll}
\hline Sharpe Ratio & $\mathbf{2 0 1 2}$ & $\mathbf{2 0 1 3}$ & $\mathbf{2 0 1 4}$ & $\mathbf{2 0 1 5}$ & $\mathbf{2 0 1 6}$ & $\mathbf{2 0 1 7}$ & $\mathbf{2 0 1 8}$ \\
\hline Value Stocks & 7,94 & $(2.28)$ & 3,86 & $(6.32)$ & 1,10 & $(0.14)$ & $(5.88)$ \\
\hline Control & 4,32 & $(3.47)$ & 2,98 & $(4.48)$ & $(2.01)$ & 2,98 & $(4.23)$ \\
\hline
\end{tabular}

As per the above-mentioned data, the value portfolio has recorded higher Sharpe Ratios during the years of positive returns (2012, 2013, 2016, excluding 2017) relative to the control portfolio. It is evident that our value portfolios provide higher returns compared with their risks.

\subsection{Data Analysis for Growth Shares and Portfolio Selection}

As commented earlier, $\mathrm{P} / \mathrm{E}$ and $\mathrm{P} / \mathrm{B}$ ratios were distinguished as the key multiples for value investing and investors seek lower $\mathrm{P} / \mathrm{E}$ and $\mathrm{P} / \mathrm{B}$ ratios. A similar analysis and methodology were applied to the growth portfolios comprised of growth shares with lower $\mathrm{P} / \mathrm{B}$ ratios. The yearly $\mathrm{P} / \mathrm{B}$ ratios as per the analysis, are presented in Table 6.

Table 6: Price/Book Ratios - Yearly

\begin{tabular}{lcccccccc}
\hline $\begin{array}{l}\text { Average } \\
\begin{array}{l}\text { P/B } \\
\text { Ratio }\end{array}\end{array}$ & $\mathbf{2 0 1 1}$ & $\mathbf{2 0 1 2}$ & $\mathbf{2 0 1 3}$ & $\mathbf{2 0 1 4}$ & $\mathbf{2 0 1 5}$ & $\mathbf{2 0 1 6}$ & $\mathbf{2 0 1 7}$ & $\mathbf{2 0 1 8}$ \\
\hline VAKBN & 0.97 & 0.92 & 1.04 & 0.88 & 0.74 & 0.64 & 0.75 & 0.52 \\
\hline SKBNK & 0.74 & 0.74 & 0.98 & 0.97 & 0.79 & 0.60 & 0.61 & 0.62 \\
\hline
\end{tabular}

${ }^{2}$ Average $\% 110$.

${ }^{3}$ Lower loss.

${ }^{4}$ Value trap is a stock perceived to be cheaply priced because it has been trading at low valuation metrics and multiples such as profits, cash flows and P/B for an extended time period. These stocks receive interest from investors because they are considered as cheap relative to their historical valuation of the shares and relative to their peers. The value trap presents itself as the stock price continues to decline after the investor buys into the shares. 


\begin{tabular}{lllllllll} 
ISCTR & 1.20 & 1.16 & 1.15 & 1.00 & 0.85 & 0.66 & 0.81 & 0.57 \\
\hline HALKB & 1.87 & 1.80 & 1.64 & 1.21 & 0.90 & 0.58 & 0.66 & 0.36 \\
\hline GARAN & 1.77 & 1.64 & 1.61 & 1.42 & 1.28 & 1.01 & 1.09 & 0.85 \\
\hline AKBNK & 1.64 & 1.55 & 1.53 & 1.35 & 1.20 & 1.12 & 1.09 & 0.77 \\
\hline
\end{tabular}

Table 7 represents the lowest $\mathrm{P} / \mathrm{B}$ ratios by each public and private banks.

The growth stocks portfolios are conducted by the picked public and private banks are as seen in the below table.

Table 7: Growth Shares - Yearly

\begin{tabular}{lccccccc}
\hline Growth Stocks & $\mathbf{2 0 1 2}$ & $\mathbf{2 0 1 3}$ & $\mathbf{2 0 1 4}$ & $\mathbf{2 0 1 5}$ & $\mathbf{2 0 1 6}$ & $\mathbf{2 0 1 7}$ & $\mathbf{2 0 1 8}$ \\
\hline Public & SKBNK & SKBNK & SKBNK & VAKBN & VAKBN & HALKB & SKBNK \\
\hline Private & ISCTR & ISCTR & ISCTR & ISCTR & ISCTR & ISCTR & ISCTR \\
\hline
\end{tabular}

\subsection{Performance Analysis and Benchmarking of the Growth Portfolio}

Average rate of returns of growth Stocks portfolio were benchmarked against three different asset groups for performance evaluation. Control stocks cover the banking stocks not included in the value stocks. Risk Free Treasury Rate refers to the annual rate of return of the Treasury bills and BIST 100 index average annual returns are referred to as BIST 100 in the Table below. Average rate of returns of growth portfolio and other portfolios are provided below:

Table 8: Average Rate of Returns on Portfolio Basis

\begin{tabular}{lccccccc}
\hline ARR of Portfolio & $\mathbf{2 0 1 2}$ & $\mathbf{2 0 1 3}$ & $\mathbf{2 0 1 4}$ & $\mathbf{2 0 1 5}$ & $\mathbf{2 0 1 6}$ & $\mathbf{2 0 1 7}$ & $\mathbf{2 0 1 8}$ \\
\hline Growth Stocks & $\mathbf{7 8 . 2 \%}$ & $-8.4 \%$ & $34.0 \%$ & $-33.2 \%$ & $16.4 \%$ & $9.6 \%$ & $-41.1 \%$ \\
\hline Control & $48.6 \%$ & $-24.4 \%$ & $45.7 \%$ & $-23.6 \%$ & $-3.5 \%$ & $36.4 \%$ & $-35.9 \%$ \\
\hline Risk Free & $8.7 \%$ & $8.0 \%$ & $9.3 \%$ & $9.3 \%$ & $10.2 \%$ & $11.1 \%$ & $15.9 \%$ \\
\hline Bist 100 & $45.2 \%$ & $-11.3 \%$ & $25.8 \%$ & $-16.7 \%$ & $9.9 \%$ & $41.2 \%$ & $-21.5 \%$ \\
\hline
\end{tabular}

Figure 2: Cumulative Return Index of Growth Portfolio and Other Portfolios

\section{Cumulative Returns Growth Stocks vs Control, 10-years Bond, Bist100}

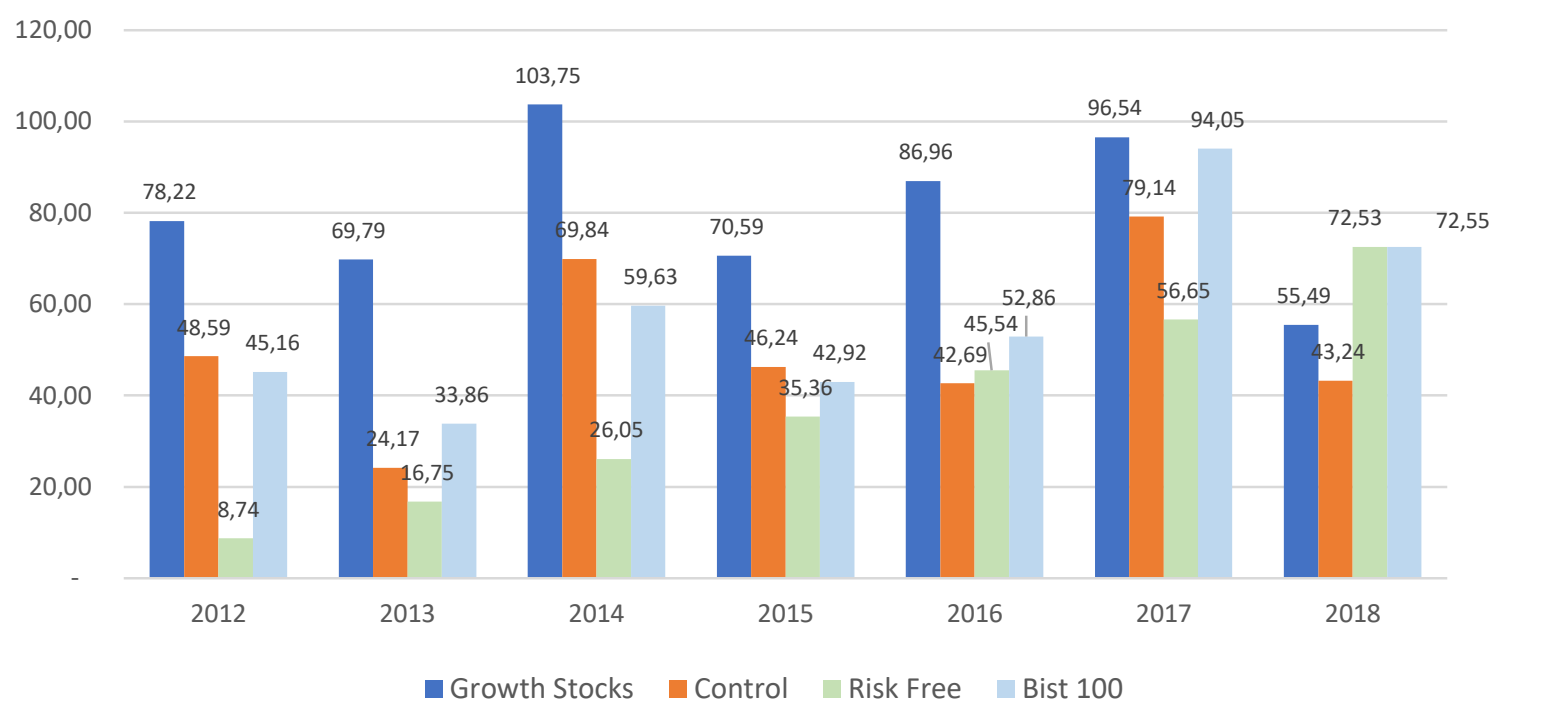


Table 9: Cumulative Return Index of Growth Portfolio and Other Portfolios

\begin{tabular}{llllllll}
\hline $\begin{array}{l}\text { Cumulative Returns } \\
\text { Index }\end{array}$ & $\mathbf{2 0 1 2}$ & $\mathbf{2 0 1 3}$ & $\mathbf{2 0 1 4}$ & $\mathbf{2 0 1 5}$ & $\mathbf{2 0 1 6}$ & $\mathbf{2 0 1 7}$ & $\mathbf{2 0 1 8}$ \\
\hline Growth Stocks & 78.22 & 69.79 & 103.75 & 70.59 & 86.96 & 96.54 & 55.49 \\
\hline Control & 48.59 & 24.17 & 69.84 & 46.24 & 42.69 & 79.14 & 43.24 \\
\hline Risk Free & 8.74 & 16.75 & 26.05 & 35.36 & 45.54 & 56.65 & 72.53 \\
\hline Bist 100 & 45.16 & 33.86 & 59.63 & 42.92 & 52.86 & 94.05 & 72.55 \\
\hline Growth vs Control \% & $61.0 \%$ & $188.7 \%$ & $48.5 \%$ & $52.7 \%$ & $103.7 \%$ & $22.0 \%$ & $28.3 \%$ \\
\hline
\end{tabular}

Table 10: Sharpe Ratios - Growth Stocks - Yearly

\begin{tabular}{llllllll}
\hline Sharpe Ratio & $\mathbf{2 0 1 2}$ & $\mathbf{2 0 1 3}$ & $\mathbf{2 0 1 4}$ & $\mathbf{2 0 1 5}$ & $\mathbf{2 0 1 6}$ & $\mathbf{2 0 1 7}$ & $\mathbf{2 0 1 8}$ \\
\hline Growth Stocks & 7.94 & $(2.28)$ & 2.58 & $(5.47)$ & 1.10 & $(0.14)$ & $(4.76)$ \\
\hline Control Stocks & 4.32 & $(3.47)$ & 3.62 & $(4.83)$ & $(2.01)$ & 2.98 & $(4.70)$ \\
\hline
\end{tabular}

As illustrated by the graphs and tables above, value investing portfolios have provided higher returns than growth investing portfolios.

\subsection{Mathematical Modelling of Value Shares and Growth Shares}

Besides the basic portfolio performance calculations, multivariable panel data regression modelling to elaborate the results and test the hypothesis in mathematical modelling was also applied.

Cross-sectional and time series which are two dimensions of panel data when regressed differs as a model from an OLS regression due to the information it makes available with respect to individuals and over time. Below is described the basic model of panel data;

$$
y_{i t}=\alpha_{i}+\sum_{k=1}^{k} x_{i t} \cdot \beta_{k i t}+\varepsilon_{i t}
$$

Where:

$\mathrm{i}=1 \ldots, \mathrm{N}, \mathrm{N}$ is the number of cross-sectional dimension (or individuals);

$\mathrm{t}=1, \ldots, \mathrm{T}, \mathrm{T}$ is the number of time dimension (or period).

Although, several panel data types are accessible; usually, fixed and random effects models are the ones mostly applied in analyses. However, in this study, only the fixed effects model was engaged and validated through estimation. Since the estimation by which the OLS (Ordinary Least Squares) hypotheses were conducted and were premised on the notion that the regression model is the same for both panel data and linear regression. (Bălă \& Prada, 2014).

The value portfolios and growth portfolios were designed and conducted for 7 years, in a row, in the study. Then the dummy variables which refer to both value stocks (Appendix I) and growth stocks (Appendix II) were applied to the model. The endeavour was to measure if the selected portfolios are outperforming the control group by calculating the coefficients of the dummy variables in the model. The analysis concludes that, a value portfolio which comprised of banking stocks that have been selected on Price-to-Earning criteria, outperforms the Control Group by \%15.

\begin{tabular}{r|r} 
lnclose | & Coef. \\
FK | & .0032365 \\
InPDDD | & .1869638 \\
DOSK | & .0023803 \\
Private | & 0 \\
value | & .1499873 \\
cons | & 1.50748
\end{tabular}


The analyses reveal similar results for growth stocks. The growth stocks selected on Price-to-Book criteria, outperforms the Control Group by \%9.8.

\begin{tabular}{r|r} 
InClose | & Coef. \\
FK | & .0006442 \\
InPDDD | & .1874643 \\
DOSK | & .0025554 \\
Private | & 0 \\
Growth | & .0976227 \\
cons | & 1.542349
\end{tabular}

The four types of variation produce $\mathrm{R}$ Square results which when observed shows the impact is less strong to the desired $\mathrm{R} 2=$ .29 for Value Stocks and R2 $=.20$ for growth stocks, respectively. Yet, since refinement of the model is permissible through additional variables which correlation becomes essential for the in-between variation, meaning there is a major effect of value stocks and growth stocks on portfolio performances.

To rely on the data and analysis of Appendix I\&II, it was also required to test heteroskedasticity in cross-sectional time series whether our data was stationary and not obviously following a trend which drags the variance of the serial and exhibit the results that the null hypothesis of a unit root can be rejected. Accordingly, to test statistics, we applied Dickey-Fuller Test (a Fisher Type Test) as seen (Appendix III) to our data. With using 0 lags of "log of closing prices", it can be rejected that the null hypothesis of data has a unit root assumption at common statistically significant levels. Thus, it was concluded that the data series of "log of closing prices" are being stationary for using statistical modelling methods under the assumption of $(\boldsymbol{p}<0.05)$ confidence level.

\section{DISCUSSION AND CONCLUSION}

As a contribution to the literature on BIST, Turkey, the study's evidence that value portfolio lost its value by more than $2 x$ than the market average in 2018 , indicating a value trap that could occur in bear market conditions; the reliability of the argument advanced by the study could further benefit from being tested for longer periods. Moreover, in relation to the results that are given to the $R$ Square for the four variation types with the observation of a correlation less strong than the desired R2 =.29 for Value Stocks and R2 = .20 for growth stocks; the model can be refined through an addition of more variables in relation to the major effect of value stocks and growth stocks on portfolio performances. The analysis is based on $\mathrm{P} / \mathrm{E}$ and $\mathrm{P} / \mathrm{B}$ ratios considered as the basic multiples for the value investment strategy. The stocks were classified by their monthly P/E ratios. BIST-100, MATRIKS DATA ${ }^{\mathrm{TM}}$ database was used to compile data for six selected banking stocks for the 95 months period between February 2011 to December 2018. One state and one private bank share with the lowest P/E multiple have been selected by the end of each financial year. The performance of the selected portfolio was benchmarked over the control portfolio for the relevant financial year.

In line with the results of the analysis and as observed in developed markets, the value investing strategies implemented for the selected banking shares listed in BIST-100, have offered significantly high returns to the investors. An investing strategy grounded on $\mathrm{P} / \mathrm{E}$ ratio is more profitable than a value investing strategy relying on $\mathrm{P} / \mathrm{B}$ ratio. The results of the study have indicated that selected shares referred to the value investing concept have yielded superior returns compared to benchmark portfolio. It is observed that the value stocks portfolio has provided a higher return (\%15) than the growth stocks portfolio $(\% 9,8)$. As a reservation, such an investment strategy could increase risks in bear markets and could mislead investors to value traps thus risk averse investors should have a cautious approach to follow value investing strategies in adverse market conditions.

\section{REFERENCES}

Bala, R. M., Prada, E. M. (2014). Migration and private consumption in Europe: A Panel Data Analysis. Procedia Economics and Finance, V.10, 141-148. https://doi.org/10.1016/S2212-5671(14)00287-1

Bellone, B., Carvalho, R. L. (2021). Value Investing: Capitulation or Opportunity?

SSRN: https://ssrn.com/abstract=3796005 or http://dx.doi.org/10.2139/ssrn.3796005

Blitz, D., Hanauer, M.X. (2020). Resurrecting the value premium. The Journal of Portfolio Management, 47(2), 63-81. 
Browne, C. H. (2007). The little book of value investing. New Jersey, John Wiley\&Sons Inc.

Capaul, C., Rowley, I., Sharpe, W. F. (1993). International value and growth stock returns. Financial Analysts Journal.49, 27-36. DOI:10.2469/FAJ.V49.N1.27

Fama, E.F. \& French, K.R. (1992). The cross-section of expected stock returns. The Journal of Finance, 47(2), 427 - 465. https://doi.org/10.1111/j.1540-6261.1992.tb04398.x

Fama, E. F., French, K. R. (1998). Value versus growth: the international evidence. The Journal of Finance, 53(6), 19751999. DOI:10.2139/SSRN.2358

Gonenc, H., Karan, M. B. (2003). Do value stocks earn higher returns than growth stocks in an emerging market? Evidence from the Istanbul stock exchange. Journal of International Financial Management and Accounting, 14(1), 1-25. DOI: 10.2139/ssrn.266048

Graham, B. (1949). The intelligent investor: The definitive book on value investing. New York, Harper \& Brothers.

Graham, B., Dodd, D. (1934). Security analysis. United States, Whittlesey House, McGraw-Hill Book Co.

Hakansson, E. and Kvarnmark, P., (2016). Value investing on the Nordic Stock Market does the magic formula constitute a viable strategy for outperforming the market? LUP Student Papers. Department of Economics. NEKH01-Bachelor Thesis, 20162.

Karcıoglu, R., Yıldırım, R. (2017). Değere dayalı portföy seçiminde çok amaçlı bulanık optimizasyon yönteminin kullanılması. Atatürk Üniversitesi iktisadi Idari Bilimler Dergisi, 31(4): 857-874, Retrieved from https://dergipark.org.tr/tr/pub/atauniiibd/issue/30589/296986

Klarman, S. A. (1991). Margin of safety: Risk-averse value investing strategies for the thoughtful investor. United States, HarperCollins.

Lakonishok, J., Shleifer, A. and Vishny, R. (1994). Contrarian investment, extrapolation, and risk. The Journal of Finance, 49(5), $1541-1578$. https://doi.org/10.1111/j.1540-6261.1994.tb04772.x

Lee, C.M.C. (2014). Value investing: Bridging theory and practice. China Accounting and Finance Review (CAFR), 16(2), $2014-2019$. DOI: $10.7603 /$ s40570-014-0005-3

Mohanram, P. (2005). Separating winners from losers among low book-to-market stocks using financial statement analysis. Review of Accounting Studies, 10 (2), 133-170. DOI: 10.1007/s11142-005-1526-4

Pätäri, E., Leivo, T. (2009). Performance of the value strategies in the Finnish Stock Markets. Journal of Money, Investment and Banking, 2 (8), 5-24

Piotroski, J. (2000), Value investing: The use of historical financial statement information to separate winners from losers. Journal of Accounting Research, 38 (Supplement), 1-41. DOI: 10.2307/2672906

Sareewiwatthana, P. (2014). PE growth and risk: Evidences from value investing in Thailand. Technology and Investment, 5(2), DOI:10.4236/ti.2014.52012

Sharpe, W. F., Capaul, C. And Rowley, I. (1993). International value and growth stock returns. Financial Analysts Journal, 49(1), 27-36 https://doi.org/10.2469/faj.v49.n1.27

Srivastava, A. and Lev, B., (2019). Explaining the recent failure of value investing. NYU Stern School of Business, SSRN, DOI:10.2139/ssrn.3442539

\section{APPENDIX I: Value Stocks Multivariable Regression Mode}

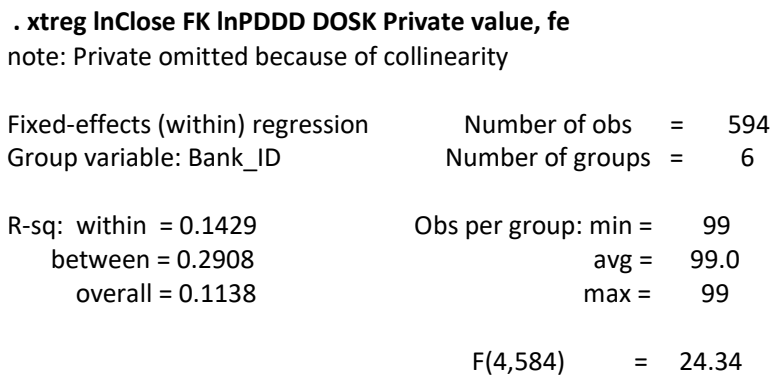

InClose | Coef. Std. Err. $\mathrm{t} \quad \mathrm{P}>|\mathrm{t}| \quad$ [95\% Conf. Interval] 


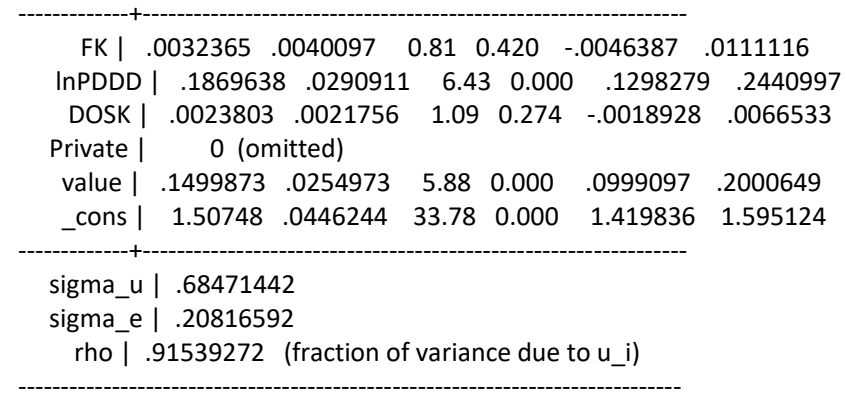

F test that all $u_{-} i=0: \quad F(5,584)=643.96 \quad$ Prob $>F=0.0000$

A fixed-effect multiple regression model was run to predict natural log (In) value of Shares Closing Price's (InClose) from Priceto-Equity (FK), In Market-to-Book ratio (InPDDD), Return-on-Equity (DOSK), Value Stocks (value) as dummy variable. These variables statistically significantly predicted $\operatorname{InClose}, F(4,584)=24.34, p<.0005, R 2=.29$ (between).

\section{APPENDIX II: Growth Stocks Multivariable Regression Model}

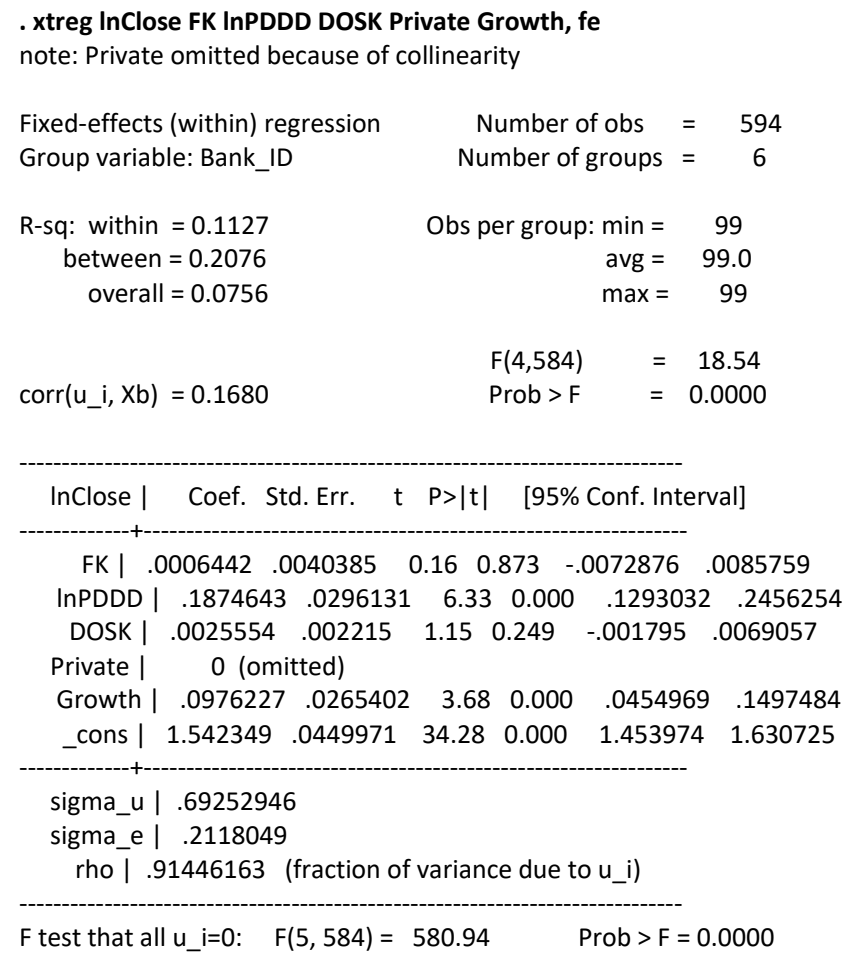

A fixed-effect multiple regression model was run to predict natural log (In) value of Shares Closing Price's (InClose) from Priceto-Equity (FK), In Market-to-Book ratio (InPDDD), Return-on-Equity (DOSK), Growth Stocks (Growth) as dummy variable. These variables statistically significantly predicted $\operatorname{lnClose}, F(4,584)=18.54, R 2=.20$ (between). 


\section{APPENDIX III}

. xtunitroot fisher InClose, dfuller lags(0)

( 2 missing values generated)

Fisher-type unit-root test for InClose

Based on augmented Dickey-Fuller tests

Ho: All panels contain unit roots

Number of panels $=6$

$\mathrm{Ha}$ : At least one panel is stationary

Number of periods $=99$

AR parameter: Panel-specific

Asymptotics: T -> Infinity

Panel means: Included

Time trend: Not included

Drift term: Not included

ADF regressions: 0 lags

Statistic p-value

Inverse chi-squared(12) P $18.8214 \quad 0.0929$

$\begin{array}{llll}\text { Inverse normal } & Z & -1.7400 & 0.0409\end{array}$

Inverse logit $\mathrm{t}(34) \quad \mathrm{L}^{*} \quad-1.6581 \quad 0.0533$

Modified inv. chi-squared Pm $\quad 1.3924 \quad 0.0819$

P statistic requires number of panels to be finite.

Other statistics are suitable for finite or infinite number of panels. 